\title{
The anti deflation bias
}

\author{
PHILIPP BAGUS*
}

Department of Applied Economics I, Economic History, and Institutions, and Moral Philosophy, King Juan Carlos University, Campus of Vicalvaro, Faculty of Legal and Social Sciences, Paseo de los Artilleros s/n, Madrid, 28032, Spain

Received: April 06, 2018 - Revised manuscript received: June 29, 2019 • Accepted: July 08, 2019

(c) 2020 Akadémiai Kiadó, Budapest

\section{ABSTRACT}

Deflation is widely feared and opposed. This paper provides arguments to explain the anti-deflationary bias. It is argued that governments favour inflation, that the main deflation theories have influenced negatively the public opinion on deflation, and that rent-seeking behaviour and group formation explains why the opposition to deflationary redistribution is stronger than the opposition to inflationary redistribution. Moreover, psychological concepts, such as anchoring, the endowment effect or the availability heuristic have contributed to the fear of deflation by causing a money illusion and a equalisation of deflation and recession.

\section{KEYWORDS}

monetary policy, inflation, deflation, money illusion, endowment effect

JEL CLASSIFICATION INDICES

E52, E31, E70, G40

\section{INTRODUCTION}

Deflation is widely feared and opposed. Ben Bernanke (2002), the Chair of the Board of the Federal Reserve System (FED), asserted in a well-known speech titled "Deflation - making sure it doesn't happen here" that central banks in a fiat money system can and should prevent deflation. Christine Lagard, a former French Minister of the Economy, Finance and Industry and for many years the Managing Director of the International Monetary Fund (IMF), claimed

*Corresponding author. E-mail: philipp.bagus@urjc.es 
that deflation is the ogre that must be fought decisively. Similarly, Mario Draghi, a former President of the European Central Bank (ECB), considered that deflation was a threat even though the Eurozone consistently experienced price inflation during his term. ${ }^{1}$

Following this fear of deflation, monetary policy has been largely inflationary. As an example, in 2014 the ECB justified its quantitative easing program with the threat of deflation (Praet 2018). The inflationary bias of monetary policy has traditionally been explained by the seminal time inconsistency model developed by Barro - Gordon. ${ }^{2}$

In this article, I take a complementary approach applying the rent-seeking theory, the theory of group formation, and the insights from behavioural economics to monetary policy. Comparing the views on inflation and deflation, I analyse if there exist any political and psychological reasons for an asymetrical fear of deflation, its vehement opposition and the ubiquitous inflationary environment.

It is out of the scope of this paper to ask that in which cases and to which extent deflation is actually harmful to the economy. The aim of the paper is to investigate if there are reasons to be overfearful of deflation and if there may exist an anti-deflationary bias. Even though I did it in other publications (Bagus 2003, 2006, 2015), I will not investigate here the controversial question if deflation actually has more harmful effects on the economy than inflation. I will rather show that just considering the redistributional effects of inflation and deflation as well as rent-seeking, group theory and behavioural economics, we can predict a deflation fear or a antideflationary bias. Considering the redistributional effects of inflation and deflation as well as the psychological nature of human beings, it is not surprising that we experience more often inflation than deflation. In analysing the political economy of inflation and deflation, public choice arguments as well as psychological arguments will help to explain why there is an antideflationary bias and a tendency towards an inflationary world.

\section{DEFLATION THEORIES, THE GOVERNMENT AND PUBLIC OPINION}

Theories influence the ideas that people have. If people hold the idea that something is bad for them, they will oppose this something. Most contemporaneous economic theories regard deflation as something harmful. In the orthodox economics, there are basically two main strands in the contemporary deflation theories.

The first strand has representatives like Claudio Borio, Andrew Filardo, Michael Bordo, John L. Lane, and Angela Redish. ${ }^{3}$ Because this group views deflation as being good at times and not at others, they might be called the Good-versus-Bad deflation school. For Good-versus-Bad deflation theorists, deflation has basically two causes (Bordo et al. 2004: 15). One is economic growth or positive aggregate supply shocks. There are high profits, asset prices, and rising real

\footnotetext{
${ }^{1}$ See, for instance, Draghi (2017). Draghi did not even want price inflation comes close to zero.

${ }^{2}$ See Barro - Gordon (1983a, 1983b). Barro and Gordon build on Kydlant - Prescott (1977).

${ }^{3}$ For a book of selected essays that stand in this tradition, see Burdekin - Siklos (2004a, 2004b). Good deflation is caused by a positive supply shock and bad deflation by a negative demand shock. In particular, see Burdekin -- Siklos (2004b) and Bordo - Redish (2004). Borio - Filardo (2004: 7) even distinguish three types of deflation: "the good, the bad and the ugly." Good deflations are caused by productivity increases. Bad deflations are caused by nominal rigidities, while ugly deflations disrupt the economy in a self-reinforcing spiral.
} 
wages accompanied by a strong financial sector. This deflation they consider to be a good one. The other cause is a negative demand shock with a non-vertical aggregate supply curve. As these negative demand shocks would have negative output effects, this type of deflation is considered to be a bad one. Furthermore, these theorists argue that deflation produces only negative consequences when it is unexpected. ${ }^{4}$

The second strand is represented by economists like Ben Bernanke, Lars E.O. Svensson, Marvin Goodfriend and Paul Krugman. This group fears that deflation might put the economy in a liquidity trap and therefore categorically opposes deflation. This is deflation phobia in its clearest form.

A third opinion is represented by - what I call - the liquidity trap group. For them, deflation "is seldom benign," and even when stemming from a positive supply shock, it can lead to a deflationary spiral of prices and output (Kumar et al. 2003). Svensson (2003: 145) states that it is uncontroversial that a liquidity trap and deflation should be avoided. According to this view, the unanticipated negative demand shocks may cause recession and deflation. Also, the substantial realized or anticipated negative aggregate demand shocks, like bursts of asset price bubbles, doubts about government policies, or corrections of overly optimistic expectations would lower inflation and output and their respective forecasts (Svensson 2003: 146). In this situation the central bank should lower interest rates to stimulate aggregate spending. However, when prices are expected to fall a negative inflation premium is included in nominal interest rates which may become very low. It might be impossible to lower interest rates sufficiently as nominal interest rates cannot fall below zero. The central bank, as feared, has "run out of ammunition." The real cost of borrowing will be on a level higher than that is necessary to stimulate the economy. The ineffectiveness of monetary policy is seen as a main threat of deflation. Considerable intellectual effort is spent in finding ways out of a liquidity trap via inflation of the money supply. Thus, these theorists argue for an inflation rate that has some buffer against the danger of price deflation. ${ }^{5}$

Arguably, theories have an important impact on public opinion and help to explain the fear of deflation. However, the creators of theories can be themselves influenced by certain incentives. Nowadays, economic research in the money area is sponsored mainly by the government university system and the banking system. Governments oppose deflation as will be explained below.

The banking system opposes deflation, because it could trigger a liquidation spiral and benefits from expansionary monetary policies. As the central banks and fractional reserve banks are both debtors and creditors simultaneously, one could argue that the banks would not gain either by price inflation or by price deflation. However, price deflation can trigger bankruptcies and, thereby, cause important losses for banks, that can develop into a debt deflation spiral and a collapse of the banking system (Fisher 1933). Banks, therefore, prefer a moderate price inflation. More importantly, banks benefit directly from credit expansion, which increases the money supply and, ceteris paribus, prices. ${ }^{6}$

\footnotetext{
${ }^{4}$ Sargent - Wallace (1976: 175) argued that the fully anticipated price changes would not have any effect on the real economic activity. This implies that a fully anticipated deflation would also have no adverse effect on the economic activity.

${ }^{5}$ For example, Svensson (2003: 30) justifies an inflation targeting of 2 per cent instead of 0 per cent by the negative effects of price deflation.

${ }^{6}$ See, for instance, Huerta de Soto (2012) for the process of credit expansion of a fractional reserve banking system.
} 
The banking system exerts influence on the academic literature. To grasp the influence of the FED on academic output, White (2005: 325) points out "some 74 percent of the articles on monetary policy published by US-based economist in US-edited journals appear in Fed-published journals or a co-authored by Fed staff economists." The academic ideas concerning deflation are, then, brought to the general public via "second-hand dealers" of ideas, like the media and teachers. ${ }^{7}$

\section{WHY GOVERNMENTS TEND TO PREFER INFLATION}

It is true that the fear of something supposedly bad (deflation) does not necessarily mean that one has to endorse an opposite of bad (inflation). Officially, monetary policies are indeed antiinflationary. The long-term empirical evidence shows, however, significant price inflation. Particularly, when the central banks became more autonomous in their monetary policy after the end of the gold standard with its inherent restrictions, price inflation increased (Figure 1). ${ }^{8,9}$

It is also true that there have been theoretical justifications for positive low inflation (1-2 per cent). ${ }^{10}$

My argument is that even if monetary policy had been anti-inflationary and the theoretical justifications would hold, there exist some reasons why the governments favour (moderate) price inflation out of pure self-interest.

The central banks buy government bonds from banks in open market operations. Via expansionary monetary policies the demand for government bonds increases. Thus, the governments can indebt itself to a much higher degree than without the monetary inflation. ${ }^{11}$ This allows the governments to ignore fiscal resistance to increased spending. This is especially important in times of war when the governments try to hide the real costs of war by financing it via the printing press (Salerno 1999; Selgin - White 1999). Hence, the governments can spend more and command more resources of society than without the monetary inflation.

In a monetary deflation or credit contraction this way to finance government debt is disturbed. For these reasons, deflation has been unpopular among interests connected with the state (Mises 1971: 231-232). The advantages politicians and bureaucrats derive from an expansionary monetary policy, thus, can explain a great part of the pro-inflationary and anti-deflationary bias. However, there is another reason why politicians fear deflation. Deflation increases the real burden of debt and, consequently, leads to a redistribution from debtors to creditors. This has an important effect as historically the biggest debtor in an economy is always the state. ${ }^{12}$ The real

\footnotetext{
${ }^{7}$ On the influence of second-hand dealers of ideas see Hayek (1998).

${ }^{8}$ See, for instance, price inflation in the last 300 years in the United Kingdom in MacFarlane - Mortimer-Lee (1994: 157).

${ }^{9}$ Consumer price index for all urban consumers: All items in the U.S. city average. Shaded areas indicate the U.S. recessions.

${ }^{10}$ Moderate positive price inflation targets have been justified by quality effects of innovations, the Balassa-Samuelson effect, substitution effects, etc.

${ }^{11}$ It may be, correctly, argued that only moderate inflation is in the interest of government. When inflation gets out of control, risk and price premiums in the interest soar, creating a problem for the government.

${ }^{12}$ The 22 trillion \$ of U.S. government debt (https://www.treasurydirect.gov/govt/reports/pd/mspd/2019/opds052019.pdf accessed 06/27/2019) exceeds by far the debts of any private debtor.
} 


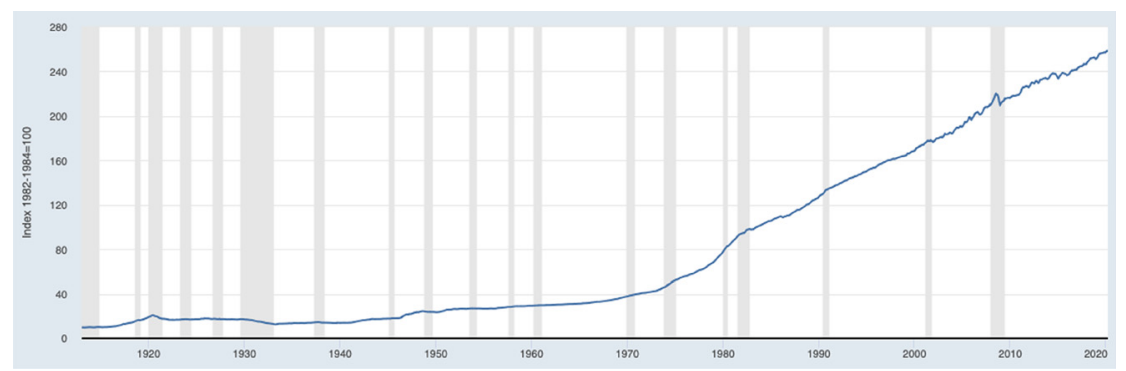

Figure 1. Consumer price inflation and deflation in the U.S. from 1913-2020. ${ }^{9}$ Source: U.S. Bureau of Labor Statistics

burden of government debt is higher than it otherwise would have been. As a consequence, a higher percentage of government revenue must be spent on debt payments. This means that a government, if it is not to increase unpopular taxes, has to reduce its spending on the other ends. Instead of engaging in popular spending programs that may result in an increase in popularity or votes, the government has to use a higher real percentage of its revenues on debt payments. The government is likely to centralize fewer functions than in times of inflation and give more freedom to private citizens. Moreover, when prices start to fall a progressive tax system will cause tax revenues to fall over proportional, i.e. the government tax revenue will fall faster than the government's costs. This "taxdeflation" deteriorates the real spending position of the government.

In sum, the state power is likely to be reduced in times of monetary deflation. Monetary deflation tends to cause price deflation. In a price deflation, the real burden of debt increases. Government revenues shrink while its nominal debts obligations remain constant. Therefore, a government might get into difficulties to finance a welfare state without the help of monetary policy.

Not only the state power shrinks during price deflation, but also price deflation's prescribed medicine is monetary inflation. This monetary inflation is, as explained above, for the benefit of the state and also its connected groups. While it is easy to understand why the governments have an anti-deflation bias, we will try to explain the deflation phobia of the general population.

\section{REDISTRIBUTION AND THE OPPOSITION TO PRICE DEFLATION}

From a theoretical point of view, we understand why there might be reasons for some people to be discontent in a time of declining prices. In economic development winning and losing depends on the anticipation of future events and the coordination of one's action in function of this anticipation. In our case, winning and losing depends on the anticipation of falling prices and the exploitation of this anticipation. Falling prices imply losses for the entrepreneurs who did not accurately anticipate the future, paying overly high prices for factors of production, i.e., factor prices that will lead them to incur losses. Also, those individuals lose whose real burden of debt is rising higher than otherwise would have been the case. ${ }^{13}$ During a deflation debtors lose

\footnotetext{
${ }^{13}$ Again this is true for both expected (anticipated) and unexpected (unanticipated) deflation.
} 
and creditors win. This helps to explain the historically strong opposition toward deflation as traditionally the establishment is indebted and creditors are hated (Mises 1971: 232). In the following, we shall analyse in more detail why the redistribution caused by deflation is opposed more vehemently and effectively than the redistribution caused by deflation.

\subsection{Apparentness of losses}

The redistributional effects of price deflation go in the opposite direction of those of an price inflation when the creditors lose and the debtors win as the real burden of debt is reduced. So why is there more opposition towards price deflation than towards price inflation? The effects are not exactly the opposite of those that occur in a price inflation for several reasons. First, in price inflation the redistribution is obscured more than in price deflation. In inflation creditors lose slowly, not abruptly, as the money they receive on their loans loses purchasing power. Creditors can buy fewer goods and services than they would have bought without the inflation. This loss is hardly visible, almost unseen, because people do not know what they could have bought without the inflation. People do not lose something that they already have in their possession. Rather, they cannot buy something they could have bought if there would not have been the inflation.

On the contrary, in a deflation the burden of debts may become so heavy that the debt needs to be renegotiated or the debtor goes bankrupt. In the latter case, the assets are turned over to the creditor. This is not necessarily harming production, as only the ownership of productive assets is changed and during the bankruptcy process production can go on as before. One can even argue that it would be likely that production in the long run would be fostered by this redistribution. This might be so, because the redistribution goes from people who tend to save marginally less, i.e., debtors, and to those who tend to save marginally more, i.e., creditors. Thus, total savings might be increased by such a redistribution.

The bankruptcy process, though, implies an important difference in the deflationary redistribution as opposed to the inflationary redistribution where there have been historically fewer bankruptcies than usual. The bankruptcy redistribution is highly visible and often a personal tragedy. The person who declares bankruptcy is probably more aware of his loss than the creditor who loses in inflation. He loses things that were in his possession before. Psychologically, the apparentness of losses in deflation vis-à-vis inflation makes a difference. As Kahneman - Tversky (1984) or Thaler (1980) have pointed out people are more sensitive to losses (as in a deflation) than to foregone gains (as foregone goods and services they cannot buy due to rising prices). ${ }^{14}$

These effects may be referred to as a "loss aversion" or "endowment effect". ${ }^{15}$ The loser in a deflationary redistribution will tend to feel more strongly about his loss than the winner is to feel about his gain. This is so, because people tend to value a good or asset higher when they own it

\footnotetext{
${ }^{14}$ Empirical evidence has supported the hypothesis of the existence of a "loss aversion" (see Kahneman et al. 1991 and Tversky - Kahneman 1991). Kahneman et al. (1986) showed that in the case of a wage cut (a reduction in their real wage), people prefer price inflation to price deflation.

${ }^{15}$ For the "endowment effect" see Thaler (1980) and Kahneman (2011). It is an elaboration of prospect theory (Kahneman - Tversky 1979). According to the prospect theory, individuals value an asset not absolutely but in relation to the status quo. They also tend to fear losses more than they esteem gains, i.e. there is loss aversion.
} 
than if they do not. Once people own an asset, the tendency is that they start to value it higher. This is called the "endowment effect." Consequently, when due to price deflation an asset changes ownership from the debtor to the creditor (or the debtor gets into difficulties to pay the debt to keep his asset), the debtors will, according to the "endowment effect" become quite upset when they lose assets that have become dear to them. They might protest monetary policy vehemently. The creditors, however, will esteem the gain probably not so emotionally. ${ }^{16}$ In addition, losses of things or assets tend to be weighted stronger than possible gains of the same monetary value. Loss aversion may, therefore, psychologically explain why deflation phobia is stronger than inflation phobia. This is so, because in an inflation, the redistribution is in the opposite direction from the creditor to the debtor. The creditors do not lose a particular "asset" that has become dear to them. They just lose prospective purchasing power, which has not objectified into an asset yet, so no "endowment effect" could have been developed.

Empirical research supports the role of the endowment effect in the anti-deflation bias. In a survey, students $(N=144)$ were presented with two scenarios. ${ }^{17}$ In Scenario 1, a debtor had to pay $200 €$ on a car loan, which he failed to do to due price deflation (his wage was cut by $100 €$ ). He had to give the car back to the creditor. In Scenario 2, there was the same debt relationship but prices rose 50 per cent reducing the purchasing power of the sum received by the creditor. From pure purchasing power terms, the redistribution in both scenarios was the same, both lose $100 €$. In Scenario 1, the debtor due to the wage cut and in Scenario 2, the creditor due to the price inflation. Nevertheless, 74.3 per cent of participants believed that the debtor in Scenario 1 was suffering more than the creditor in Scenario 2 (8.3 per cent sustaining that the creditor suffers more in Scenario 2 and 17.4 per cent arguing that they suffer the same).

From a moral point of view, 61.8 per cent found scenario 2 to be more just. 28.5 per cent found the scenarios are considered to be the same from a moral point of view and 9.7 per cent considered Scenario 2 to be more just. We see here, the traditional moral preperception in favour of the debtor and against the creditors. Even though the losses are the same in purchasing power terms, the losses of the debtor are considered to be more important. The implication for the economy was straightforward for the participants. 74.3 per cent of participants found the deflation scenario to be worse for the economy than the inflation scenario (with 13.9 per cent considering the inflation scenario to be worse and 11.8 per cent regarding the scenarios as equally harmful). In sum, participants had a anti-deflation bias that translated into fearing deflation more than inflation.

\subsection{Spread of losses}

In inflation, the burden of loss is usually spread over many shoulders, over large parts of the population. ${ }^{18}$ Everyone that holds or lends money is being affected in a price inflation.

\footnotetext{
${ }^{16}$ Note that we are referring here to psychological prepositions and tendencies.

${ }^{17}$ The experiment was conducted by the author. 144 undergraduate students from Faculty Economics and Business Administration at University Rey Juan Carlos in Madrid, Spain, participated.

${ }^{18}$ Public choice literature emphasises the costs of organising an interest group in order to seek wealth transfers through state intervention or to defend the group against it (Ekelund et al. 2001). If the burden is spread on few shoulders it is easier to organise interest groups that seek wealth transfers because there is a higher incentive to do so. The protest against deflation is also relatively easy to organise, when there is already an organised group that is used for other purposes.
} 
Therefore, with a slow and steady inflation, resistance or social unrest is not as likely as with a deflation. This is so because in a deflation losses usually are not spread as much. Traditionally, the sellers, whose selling proceeds are falling faster than their buying expenditure, are fewer in number and better organized than the benefiting consumers. The number of companies selling products is much lower than the number of consumers or money users. In the EU in 2016, there were 27 million active enterprises with a population of about 500 million. ${ }^{19}$

\subsection{Organisation of winners and losers}

Historically, the groups that lose in inflation are worse organised than the groups that lose in deflation. In inflation, the groups with a relatively fixed income, such as pensioners and creditors, lose. These groups are quite large as everyone holding money is affected. They tend to be poorly organised, spreading the benefits of organising across many shoulders, and making free riding easy. In contrast, the groups that lose in a deflation are normally relatively small and can organise relatively more easily. Groups with small numbers can easily form an effective interest group. This is so because the free rider problem is not so grave. The benefits from the organisation of the group are high in relation to the personal costs that the group members must assume.

Thus, traditionally the losing groups in deflation are well organised and politically influential. Groups like fractional reserve bankers, indebted farmers, and businesses are in danger of losing considerably in a deflation. ${ }^{20}$ The business groups tend to be well organized and influence politics to the detriment of consumers (and money users in our case); a phenomenon that has been termed as "regulatory capture" (Stiglitz 1971). The financial industry is particularly influential. ${ }^{21}$ The political influence of the agricultural sector can be observed by the subsidies the sector traditionally receives. The EU's Common Agricultural Policy is a famous point in case. ${ }^{22}$

The good organization of the losing groups explains the strong opposition and successful organization. Those groups have typically also had the greater political leverage. Fractional reserve bankers have been very well organized due to the connectivity of their businesses and interests. By financing government expenditure, they also have good connections with government. The farmers have managed to organize quite a substantial group as their organization offers services that can be withheld from non-members. ${ }^{23}$ Also business interests can be organized easily in small groups with strong common interests. Businesses, indeed, have much to lose in deflation. Historically, the biggest debtors often are the business elite with good connections with the

${ }^{19}$ https://ec.europa.eu/eurostat/statistics-explained/index.php/Business_demography_statistics. Accessed on June 28th 2019.

${ }^{20}$ Another losing group as mentioned in Section 3 is the government. Governments, of course, can very directly influence or pressure monetary policy.

${ }^{21}$ Rothbard (1994) showed the influence of the banking industry in the creation of the Federal Reserve. Rothbard (2011) portrays the banking industry's influence on the U.S. foreign policies.

${ }^{22}$ For an overview on the EU's Common Agricultural Policy see Ó Caithnia (2011). For an example of the discontent of indebted farmers and their political pressure in the times of price deflation, namely in the second half of the 19th century in the U.S. (Shields 1977: 201; Bagus 2015: 150-153).

${ }^{23}$ Olson (1971: 132) explained that the free rider problem can be overcome in large groups if they offer as a "by-product" services from which non-members can be excluded. For farmers these services could be farming magazines, educational services etc. In contrast, separate and selective incentives for the large group of inflation users are hard to think of. 
government. They will strongly oppose a deflation that can lead to their bankruptcy. They are normally very well organised with proven structure, are highly influential, and often "too big to fail," which implies a strong political influence. It is not surprising that they oppose falling prices since they suffer losses relative to other groups, and often suffer losses absolutely. In other words, they would profit by inflation for which they are lobbying. They are in a monopoly position of getting the newly produced money first, and thus, engaged in rent-seeking.

The groups, however, that make profits in a moderate price deflation are larger and usually not well organized. The vast masses of workers and consumers tend to profit in a (moderate) deflation. Also savers and creditors earn profits in deflation. However, as stated above, their gains tend to be spread over more shoulders than the losses. To put it bluntly: Industry and farmer associations usually are much better organized with more political leverage than consumer associations or money holders associations, which usually do not even exist. Thus, the price deflation winners will not vehemently oppose the public pressure against price deflation that those well organized groups will exert.

The current fiat money system generates strong incentives for the deflation phobia to grow. In a world of monetary and price inflation, it becomes a prudent strategy to indebt oneself in order to acquire assets, which prices will tend to rise in the long run, as well as incomes, thereby reducing the real burden of debt. ${ }^{24}$ As next to everyone is indebted, the danger of a price deflation running out of control becomes a widespread threat.

Price deflation increases real debt burdens. If many actors are highly indebted, the fall of one debtor may trigger through the domino effects a general liquidation process; a giant redistribution of assets between the creditors and the debtors. The whole financial system may collapse. While in the long run, this redistribution may actually be beneficial and lead to a sound monetary system, people fear such a process, in which uncertainty rises, and they may become temporarily unemployed. Thus, even though the economy, in general, could profit in the long run from such a deflationary collapse, the indebted individuals prefer to stay on the safe path with no apparent disruptions. They oppose price deflation and are willing to accept inflation. We may regard this reason for deflation phobia as an example of collective corruption which makes people to favour an inflationary monetary system. ${ }^{25}$

\section{MONEY ILLUSION AND DISILLUSION}

Another reason why deflation might be opposed is money illusion (Vincze 2019). ${ }^{26}$ Money illusion is a long-known phenomenon. ${ }^{27,28}$ Shafir et al. (1997: 348) defined money illusion as “a

\footnotetext{
${ }^{24}$ See Hülsmann (2013) for the debt culture in fiat money systems.

${ }^{25}$ For the term collective corruption, see Polleit (2011: 410), who defines it as "the development among the people of an increased personal interest in invasive action." In our case, a fiat money system via its debt cultures generates a personal interest among the people to prevent (strong) price deflation.

${ }^{26}$ Bordo et al. (2004) argued that possibly this was the case for the 1880 s and 1890 s.

${ }^{27}$ Diverse authors, such as Mises (1998) or Patinkin incorporated the phenomenon in their theories. Irving Fisher (1928) dedicated a whole book to the concept of money illusion. See also Howitt (1989) for the treatment of the concept of "money illusion" in the literature.

${ }^{28}$ On “money illusion” and accounting, see Fischer - Modigliani (1986) or Mises (1998).
} 
bias in the assessment of the real value of economic transactions, induced by a nominal evaluation." Using nominal values may just be easier and more natural to most people. When there is a deflation, wealth and income in nominal terms is likely to fall. The money illusion can refer, therefore, to income and wealth.

Let us first turn to income illusion. People might feel poorer even though their real income has not changed or may even be increasing. Indeed, a psychological reason exists for the fact that falling prices are opposed more than rising prices. Many people are more concerned about their future as producers than their future as consumers (Stolper 1966: 137). Thus, when prices generally fall, people tend to overlook, that many prices of the goods they buy, also fall. Rather they will concentrate on the price of the one good or service they sell. As this price, be it of labour services or of a produced good, seems so essential for the future they will oppose the price fall. A worker, whose wage falls, tends to put more weight on his wage fall than on the fact that his consumption prices also fall. A producer, whose products' prices fall, might also regard this as to weight more than that the prices of his factors of production and consumption prices also fall. In both cases, the selling price is conceived in a sense as a very "personal" price, it is his "pride." The fall of this "personal" price is opposed.

Let us now turn to wealth illusion. In a deflation, the prices of assets fall. Hence, businesses might suffer accounting losses, even though, they are not suffering losses in real terms. Besides the accounting illusion, there is also a disillusion caused by the fall in the nominal value of wealth. Due to the fall in asset prices, people might feel poorer. For instance, in a bank credit contraction during a recession, the asset prices fall. There might be a stock market crash. When stock market prices plummet, the stock market investors suffer. They suddenly become aware of the fact that they invested, to a large part, in malinvestments during the artificial boom. Of course, the malinvestments were committed probably a long time ago, but only now it becomes obvious to them that these investments were actually malinvestments. Before the stock market crash, the investors, under an illusion of wealth, were not aware of the destruction of real wealth in the malinvestments. Now, due to the asset price fall a painful disillusionment sets in.

Something similar to the stock market disillusion occurs when, in a deflation, there is a bankruptcy due to an increase in real debts. The debtor loses everything and the creditor often can only recuperate part of his investment in monetary terms. In addition, sometimes the creditor has to wait a considerable amount of time until he recuperates his investment. Due to the bankruptcy, it becomes obvious that an inviable investment project has been undertaken. The destruction of real wealth becomes evident in the bankruptcy. The illusion consisted in the fact, that before the bankruptcy, the individuals were not aware of the destruction of real wealth. They think that the bankruptcy destroyed the real wealth. Yet, the destruction happened when the investments were undertaken. It only finally becomes obvious in the bankruptcy.

There is another possible disillusion concerning the wealth of people. In a credit contraction, problems can occur for a fractional reserve banking system. When depositors cannot recuperate their deposits in total or have to wait to withdraw them, they become discontented. They are now aware that their bank has used and lent out their deposits. Their illusion that they could recuperate their deposits disappears. Yet, the incapacity of the bank to pay them out is only a manifestation of redistribution that had occurred before. 
In contrast, in (moderate) inflation, the opposite can occur. ${ }^{29}$ People feel richer, because of the accounting profits and increases in asset prices and nominal incomes. Optimism is widespread and everything seems to be possible. This explains why there is less opposition to a price inflation than to a price deflation. Hence, the money illusion and disillusion might also be a factor in explaining the social unrest.

The money illusion can be explained psychologically (Shafir et al. 1997). The framing of the transactions in terms of the nominal values incites people to use these values instead of the real ones. People tend to anchor their expectations on the nominal values. ${ }^{30}$ Price changes are compared to a past reference transaction. Anchoring implies that human beings tend to concentrate on the past nominal numbers rather than the present or future purchasing power. People tend to be biased in looking on the nominal values rather than the real ones. They may correct their assessment by taking into account the development of purchasing power, but, according to the psychological findings, it is not strong enough.

People, as a consequence, concentrate on their nominal wage or purchase price and do not rely so much on the development of purchasing power, an information only available later. In other words, when negotiating a new wage, the worker will focus on his last nominal wage (the "anchor") and negotiate accordingly. In his mental accounting, the worker operates with the nominal values. He will tend to evaluate the negotiations' result in relation to his last nominal wage and not the expected real wage. Kahneman et al. (1986: 740) maintained that due to the money illusion the wage cuts are "always perceived as losses." In their study, they found that the nominal wage cuts were regarded as unfair, while the wage increases lagging behind the rate of inflation were viewed more positively. Similarly, a home owner will consider the buying price of his home, when he calculates his real wealth or selling options. Consequently, the falling nominal wages or asset prices induce people to believe that they are poorer while that may not be the case in the real terms.

Hence, anchoring and the focus on the nominal instead of the real values explains why people fear a price deflation more than a price inflation, since a price deflation makes them appear poorer and a price inflation makes them appear richer.

\section{DEFLATION AND RECESSION}

Deflation is also opposed because it sometimes coincides with a recession and a bank credit contraction. The most famous point in this case was the Great Depression. ${ }^{31}$ However, the Great Depression can be considered as the Great Exception. Atkeson - Kehoe (2004) point out that deflation and depression seem to have been linked during the 1930s. Yet in the rest of their data for 17 countries and more than 100 years, they don't find virtually any evidence of such a link

\footnotetext{
${ }^{29}$ A hyperinflation is normally also feared. People both oppose strong deflations and strong inflations. The asymmetry occurs when it comes to moderate price inflation and moderate price deflation. Politicians, economists and most people tend not to fear a price inflation between 2 and 5 per cent. However, a price deflation of $2-5$ per cent is strongly opposed.

${ }^{30}$ Anchoring refers to a "bias" that human rely strongly on the first information (number) available or given ("anchor") when making a decision or a judgement (Tversky - Kahneman 1974).

${ }^{31}$ Another famous example is Japan's lost decade. I thank an anonymous referee for this point.
} 
between deflation and depression. ${ }^{32}$ Borio et al. (2015) analysing 38 countries during 140 years confirmed these results. Inspite of this empirical evidence, price deflation per se is regarded as harmful. Deflation is associated with recession simply because it occurred at the same time in the 1930s.

As stated above, in a recession it becomes obvious that the boom was partially an illusion and that many malinvestments were committed. Thus, people, in general, do not fare well in a recession. However, it is not only a period of disillusion but also a period of social hardship caused by the adaptation of the structure of production. Companies go bankrupt. Capital is shifted, and many people become unemployed and must find work elsewhere.

People tend to see the deflation as the cause of the recession, because in a recession there is simply sometimes a deflation at the same time. However, a simultaneous occurrence does not establish a causal relationship. For instance, it could be argued that deflation is not the cause of a recession but the consequence of the credit contraction, that itself has its roots in the bank credit expansion. Thus, the association of deflation with recession is one reason for the opposition to price deflation.

Here we can refer to the "availability heuristic" (Tversky - Kahneman 1973, 1974). According to the availability heuristic, people tend to evaluate a concept, topic, method or decision with the immediate associations and examples that come to their mind. If people associate deflation with negative consequences because examples of negative scenarios come to their mind when they hear the word, they will fear deflation even though after a more indepth analysis they would not find anything to fear. In the experiment we mentioned earlier, students $(N=144)$ where asked what they would associate with the term "deflation." The results show that the immense majority associated deflation with negative words (such as recession 71 per cent, depression 41.4 per cent, or unemployment 21.4 per cent) while positive associations were almost absent ( 3.4 per cent associated prosperity with deflation, productivity increases 6.2 per cent and innovation 0 per cent). Most likely, participants had heard of the Great Depression as an example of deflation. But they did not associate the term "deflation" with other instances of price deflation, like the price deflation in the US after the Civil War; a period of fast growth.

\section{CONCLUDING REMARKS}

There exists a widespread deflation phobia among economists, media and the public in general. Neglecting the question if deflation is really as harmful as is usually suggested, it has been demonstrated that there exist strong interests and reasons for the opposition towards deflation, as well for its fear. The government thrives in times of inflation. Banks get into troubles in a deflationary spiral. Moreover, economic theories suggest that, at least, some types of deflation are dangerous. There are also reasons why the deflationary redistribution is more opposed than the inflationary redistribution. The redistribution in deflation is more apparent, the losses tend

\footnotetext{
${ }^{32}$ It is true that extreme political movements can rise in such a scenario as the Great Depression. However, they can and have risen also in the times of price inflation. In fact, Jung (2009) argues that it was the hyperinflation of the Weimar Republic that contributed to the rise of the national socialists in Germany. In any case, the great majority of the price deflations are not linked to recession, unemployment or the uprise of extreme political movements.
} 
to be more concentrated and the groups that lose are very well organised. Collective corruption may get into the way of deflation in a highly indebted economy.

In addition, there might be also a poverty effect by declining prices. Indeed, the psychological insights help to explain an "irrational" deflation phobia. The endowment effect makes people more resistant to price deflation than price inflation as they do not want to lose assets they already own. The anchoring effect makes them prefer price inflation to price deflation because they anchor on the nominal values. Lastly, the simultaneous occurrence of deflation and recession in the past can induce people to think that the deflation is the actual cause of the recession. Negative feelings on deflation are just more available.

All this explains why there exists an anti-deflation bias as well as a strong opposition towards it and why ubiquitous inflation has taken course, once monetary policy disposed of the chains of the gold standard. Monetary policy is, most likely, based on an anti-deflationary bias, caused by the cognitive errors and the interest group pressure.

\section{REFERENCES}

Atkeson, A. - Kehoe, P. J. (2004): Deflation and Depression: Is There an Empirical Link? American Economic Review, 94(2): 99-103.

Bagus, Ph. (2003): Deflation - When Austrian Become Interventionists. Quarterly Journal of Austrian Economics, 6(4): 19-35.

Bagus, Ph. (2006): Five Common Errors about Deflation. Procesos de Mercado: Revista Europea de Economía Política, 3(1): 105-123.

Bagus, Ph. (2015): In Defense of Deflation. London: Springer.

Barro, R. J. - Gordon, D. B. (1983a): A Positive Theory of Inflation in a Natural-Rate Model. Journal of Political Economy, 91: 589-610.

Barro, R. J. - Gordon, D. B. (1983b): Rules, Discretion and Reputation in a Model of Monetary Policy. Journal of Monetary Economics, 12: 101-122.

Bernanke, B. S. (2002): Deflation: Make Sure It' Doesn't Happen Here. Speech before the National Economists Club in Washington, DC (November 21).

Bordo, M. D. - Lane, J. L. - Angela, R. (2004): Good versus Bad Deflation: Lesson from the Gold Standard Era. NBER Working Paper, No. 10329.

Bordo, M. D. - Redish, A. (2004): Is Deflation Depressing? Evidence from the Classical Gold Standard. In: Burdekin, R. C. K. - Siklos, P. L. (eds): Deflation: Current and Historical Perspectives. Cambridge: Cambridge University Press, pp. 197-217.

Borio, C. - Erdem, M. - Filardo, A. - Hofmann, B. (2015): The Costs of Deflation: A Historical Perspective. BIS Quarterly Review: 31-54, March.

Borio, C. - Filardo, A. J. (2004): Back to the Future? Assessing the Deflation Record. BIS Working Papers, No. 152.

Burdekin, R. C. K. - Siklos, P. L. (eds.) (2004): Deflation: Current and Historical Perspectives. Cambridge: Cambridge University Press.

Draghi, M. (2017): Accompanying the Recovery. Introductory Speech by Mario Draghi, President of the ECB, at the ECB Forum on Central Banking, Sintra, 27 June 2017. https://www.ecb.europa.eu/press/ key/date/2017/html/ecb.sp170627.en.html. (Accessed: 28 June 2019). 
Ekelund, R. B. Jr. - Tollison, R. D. (2001): The Interest-Group Theory of Government. In: Shughart, II, W. F. - Razzolini, L. (eds): The Elgar Companion to Public Choice. Cheltenham, UK: Edward Elgar, pp. 357-378.

Fisher, I. (1928): The Money Illusion. New York: Adelphi.

Fisher, I. (1933): The Debt-Deflation Theory of Great Depressions. Econometrica, 1(4): 337-357.

Fischer, St. - Modigliani, D. (1986): Towards an Understanding of the Real Effects and Costs of Inflation.

Review of World Economics (Weltwirtschaftliches Archiv), CXIV, 810-833 (Reprinted:Fischer, S.:

Indexing, Inflation, and Economic Policy. Cambridge: MIT Press).

Hayek, F. (1998 [1962]): The Intellectuals and Socialism. London: Institute of Economic Affairs.

Howitt, P. (1989): Money Illusion. In: Eatwell, J. - Milgate, M. - Newman, P. (eds): Money. London: The New Palgrave, Palgrave Macmillan, pp. 244-247.

Huerta de Soto, J. (2012): Money, Bank Credit and Economic Cycles. Auburn, Ala.: Ludwig von Mises Institute.

Hülsmann, J. G. (2013): Krise der Inflationskultur. München: FinanzbuchVerlag.

Jung, A. (2009): Germany in the Era of Hyperinflation. SPON. https://www.spiegel.de/international/ germany/millions-billions-trillions-germany-in-the-era-of-hyperinflation-a-641758.html. (Accessed 27 June 2019).

Kahneman, D. (2011): Thinking Fast, Thinking Slow. London: Penguin Books.

Kahneman, D. - Knetsch, J. L. - Thaler, R. H. (1986): Fairness as a Constraint on Profit Seeking: Entitlements in the Market. The American Economic Review, 76(4): 728-741.

Kahneman, D. - Knetsch, J. L. - Thaler, R. H. (1991): The Endowment Effect, Loss Aversion and Status Quo Bias. Journal of Economic Perspectives, 5(1): 193-206.

Kahneman, D. - Tversky, A. (1979): Prospect Theory: An Analysis of Decision under Risk. Econometrica, 47(2): 263-292.

Kahneman, D. - Tversky, A. (1984): Choices, Values, and Frames. American Psychologist, 39: 341-350.

Kumar, M. - Baig, S. T. - Decressin, J. - Faulkner-MacDanagh, Ch. - Feyziogulu, T. (2003): Deflation: Determinants, Risks, and Policy Options. IMF Occasional Paper, No. 221.

Kydland, F. E. - Prescott, E. C. (1977): Rules rather than Discretion: The Inconsistency of Optimal Plan. The Journal of Political Economy, 85(3): 473-492.

Luskin, D. L. (2001): The Greatest Threat Facing the U.S. Economy: Deflation. CapitalismMagazine.Com (November 19).

Goodfriend, M. (2001): Financial Stability, Deflation, and Monetary Policy. Working Paper, No. 01-01, Federal Reserve Bank of Richmond.

Macfarlane, H. - Mortimer-Lee, P. (1994): Inflation over 300 Years. Bank of England Quarterly Bulletin, pp. $156-162$.

Makin, J. H. (2001): The Deflation Monster Lives. Economic Outlook (December).

Meltzer, A. H. (2000): Monetary Policy in the New Global Economy: The Case of Japan. Cato Journal, 20(1): 69-72.

Mises, L. V. (1971): Theory of Money and Credit. Irvington-on-Hudson, NY: Foundation of Economic Education.

Ó Caithnia, B. (2011): Compounding Agricultural Poverty: How the EÚS Common Agricultural Policy is Strangling European Recovery. In: Howden, D. (ed.): Institutions in Crisis. European Perspectives on the Recession. Cheltermham, UK: Edward Elgar, 200-228.

Olson, M. (1971): The Logic of Collective Action: Public Goods and the Theory of Groups. Cambridge: Harvard University Press. 
Patinkin, D. (1965): Money, Interest, and Prices. 2nd edition, New York: Harper and Row.

Polleit, Th. (2011): Fiat Money and Collective Corruption. Quarterly Journal of Austrian Economics, 14(4): 397-415.

Praet, P. (2018): Assessment of Quantitative Easing and Challenges of Policy Normalisation. Speech by Peter Praet, Member of the Executive Board of the ECB, at "Tthe ECB and its Watchers XIX Conference", Frankfurt am Main, 14 March 2018.

Rothbard, M. N. (1994): The Case against the FED. Auburn, AL: Ludwig von Mises Institute.

Rothbard, M. N. (2011): Wallstreet, Banks and American Foreign Policy. Auburn, AL.: Ludwig von Mises Institute.

Salerno, J. T. (1999): War and the Money Machine: Concealing the Costs of War Beneath the Veil of Inflation. In: Denson, J. V. (ed.): The Costs of War. New Brunswick, NJ: Transaction Books, pp. 433-453.

Samuelson, R. J. (2001): The Specter of Deflation. The Washington Post Online (November 21), A23.

Sargent, Th. - Wallace, N. (1976): Rational Expectations and the Theory of Economic Policy. Journal of Monetary Economics, 2(2): 169-183.

Selgin, G. - White, L. (1999): A Fiscal Theory of Government's Role in Money. Economic Inquiry, 37(1): 154-165.

Shafir, E. - Diamond, P. - Tversky, A. (1997): Money Illusion. The Quarterly Journal of Economics, 112(2): 341-374.

Shields, R. E. (1977): Economic Growth with Price Deflation. New York: Arno Press.

Stiglitz, G. (1971): The Economic Theory of Regulation. The Bell Journal of Economics, 2(1): 3-21.

Stolper, G. (1966): Deutsche Wirtschaft seit 1870. (Continued by Häuser, K. - Borchardt, K.) 2nd revised edition, Tübingen: J. C. B. Mohr (Paul Siebeck).

Svensson, L.E.O. (2003): Escaping from a Liquidity Trap and Deflation: The Foolproof Way and Others. Journal of Economic Perspectives, 17(4): 145-166.

Thaler, R. H. (1980): Toward a Positive Theory of Consumer Choice. Journal of Economic Behavior and Organization, 1(1): 39-60.

Tversky, A. - Kahneman, D. (1973): Availability: A Heuristic for Judging Frequency and Probability. Cognitive Psychology, 5(2): 207-232.

Tversky, A. - Kahneman, D. (1974): Judgment under Uncertainty: Heuristics and Biases. Science, 185: $1124-1131$.

Tversky, A. - Kahneman, D. (1991): Loss Aversion and Riskless Choice: A Reference Dependent Modell. Quarterly Journal of Economics, 106(4): 1039-1061.

Vincze, J. (2019): Money Illusion: Reconsidered in the Light of Cognitive Science. Acta Oeconomica, 69(2): 191-215.

White, L. H. (2005): The Federal Reserve System's Influence on Research in Monetary Economics. Eco Journal Watch, 2(2): 325-354. 